\title{
Morphology and taxonomy of selected cymbelloid diatoms from a Mongolian Sphagnum ecosystem with a description of three species new to science
}

\author{
Maxim KulikovskiY ${ }^{1}$, Horst Lange-Bertalot ${ }^{2}$, Andrzej WitKowski ${ }^{3} \&$ \\ Nadezhda DorofeYuK ${ }^{4}$
}

${ }^{1}$ Papanin's Institute for Biology of Inland Waters Russian Academy of Sciences Russia, 152742 Yaroslavl, Nekouz, Borok; e-mail:max-kulikovsky@yandex.ru

${ }^{2}$ Faculty of Biology, Institute of Ecology, Phylogeny, Diversity, J. W. Goethe-University and Forschungungsinstitut Senckenberg, Senckenberganlage 31-33, 60054 Frankfurt am Main, Germany

${ }^{3}$ Department of Palaeoceanology, Institute of Marine Sciences, University of Szczecin, Mickiewicza 18, PL-71 415 Szczecin, Poland

${ }^{4}$ A.N. Severtsov Institute of Ecology and Evolution Russian Academy of Sciences Russia, 119071, Moscow, Lenin Avenue, 33

\begin{abstract}
The present paper focuses on selected cymbelloid diatom taxa inhabiting Nur Sphagnum bog in northern Mongolia. Samples collected in this area contained numerous species of Encyonema KüTZING and Cymbopleura (Krammer) Krammer, that are together acidobiontic, oligotraphentic taxa. Cymbopleura pernaviculiformis, Cymbopleura deviatkinii and Encyonema marvanii are described as species new to science. Furthermore, for two other species we suggest new nomenclatural combinations. The characteristics of Cymbopleura naviculiformis (Auerswald) Krammer sensu stricto are discussed in order to compare it with other species mentioned in this paper. The autecological characteristics of the new species found in Nur bog are presented.
\end{abstract}

Key words: Mongolia, Sphagnum bogs, cymbelloid diatoms, new taxa

\section{Introduction}

Diatom assemblages associated with mosses (e.g. Sphagnum spp.) and liverworts have been studied for some time (ANDo 1977, 1978); however, scientific interest in such assemblages was intensified as late as the 1990s. The studies were mainly focused on the Arctic, Antarctic and the Southern Ocean islands, e.g. Kerguelen Islands (VAN DE ViJver et al. 2001, Gremmen et al. 2007), Crozet Islands (VAN DE VIJVER et al. 2002), Southern Shetland Islands (TemnisKovaTopalova \& Chipev 2001), Southern Georgia (VAN DE ViJVER \& BEYENS 1996). In the northern hemisphere, the Canadian Arctic was the site of studies conducted by Douglas \& Smol (1995, 1999) and Antoniades et al. (2008). A series of papers concerning diatom flora of European moss habitats were also published (Central Europe: Wojtal et al. 1999, PoulíčKová et al. 2002, BuczKó 2006; European part of Russia: KULIKOvsKY 2007, 2008, 2009). As emphasized by BuczKó (2006), diatomists tend to reduce the role of mosses and consider them only as substrate, thus inferring that their taxonomy has no significance. However, the studies by PuLíčKovÁ et al. (2004) and BuczKó (2006) indicate that the relationship between moss species and diatom community structure is highly significant. This is reflected not only by their taxonomic composition, but also by the number of taxa, and furthermore biodiversity.

During the last decade a significant increase in studies of the diatom flora from different ecosystems and habitats from Mongolia has been observed. The reason for discovering this area for broad diatomological audience is that some of these habitats e.g. Lake Høvsgøl, belong in the Lake Baikal rift zone and represents one of the oldest habitats existing in the world (e.g. POPOVSKAYA et al. 2002; EDLUND et al. 2003, 2006b). Within last few years diatom assemblages of the province of Hentei were floristically studied by MetzeLtin et al. (2009). All these studies, however, considered well developed, species rich lacustrine habitats. 
The questions raised in these studies were either evolutionary (EDLund et al. 2003, 2006a) or floristic (Metzeltin et al. 2009).

A few studies on Sphagnum ecosystems of Mongolia have been completed, since they are not typical for the arid zone of Mongolia. Sphagnum ecosystems world wide play a very important role in the water balance of the regions in which they occur. In this particular case, Sphagnum bogs support the stability of the water level and surface flows in the Selenga, Yenisei and Amur basins (Gunin \& Vostokova 2005, Minaeva et al. 2005).

Mongolian Sphagnum bogs have historically been virtually unstudied, hence very little data exist about the vegetation of these ecosystems. Most data on their vegetation and diversity originated long time ago and are summarized by PaVlov (1929) and Yanatov (1950). Exceptionally comprehensive results of studies on higher plant assemblages are given by LAVRENKO (2000). Published information regarding the algal flora of Nur bog is lacking, and diatoms have received no attention at all. Thus this paper presents the first data on some aspects of diatom assemblages of Nur bog. Though the diatom assemblage is rich in species number in this paper we only focus on a few cymbelloid species occurring in Nur bog. Based on Krammer (1982, 1997a, 1997b, 2003) we have made an attempt to establish their taxonomic position. Some of them were found in literature as various infraspecific categories (e.g.
Foged 1953, Lange-Bertalot \& Genkal 1999, Krammer 2003). Sometimes a single taxonomic entity was recorded under several names (e.g. Encyonema marvanii = Cymbella affinis var. semicircularis Lagerstedt sensu Cleve-Euler, 1955 and Encyonema (? nov.) spec. in LANGEBertalot \& Genkal (1999: Figs 61, 9). Their relatively abundant occurrence in the material from Nur bog in Mongolia enabled us to carry out detailed ultrastructural studies by means of electron microscopy. This in turn helped us in their taxonomic revision.

\section{Material and methods}

The material used in the present study was collected from different parts of the Nur bog (Northern Mongolia) on September the $5^{\text {th }} 2005$. Altogether 12 samples were collected from Sphagnum spp. Water temperature at the studied localities varied from 11 to $13{ }^{\circ} \mathrm{C}$ and the $\mathrm{pH}$ from 5.5 to 5.6.

The Nur Sphagnum bog (N 49³8'; E10748') represents the largest wetland area in Mongolia (Fig. 1). It is situated in the mountain taiga forest (1348-1351 m a.s.l) in the northern part of the Hentei highlands that include the Huder sum. It is a system of peatlands, consisting of several groups, situated on the flat terraces of the mountain saddle. There are more than 10 species of the Sphagnum genus there. Herb layer is dominated by Carex rostrata with codomination of Eriophorum polystachion, Scheuchzeria

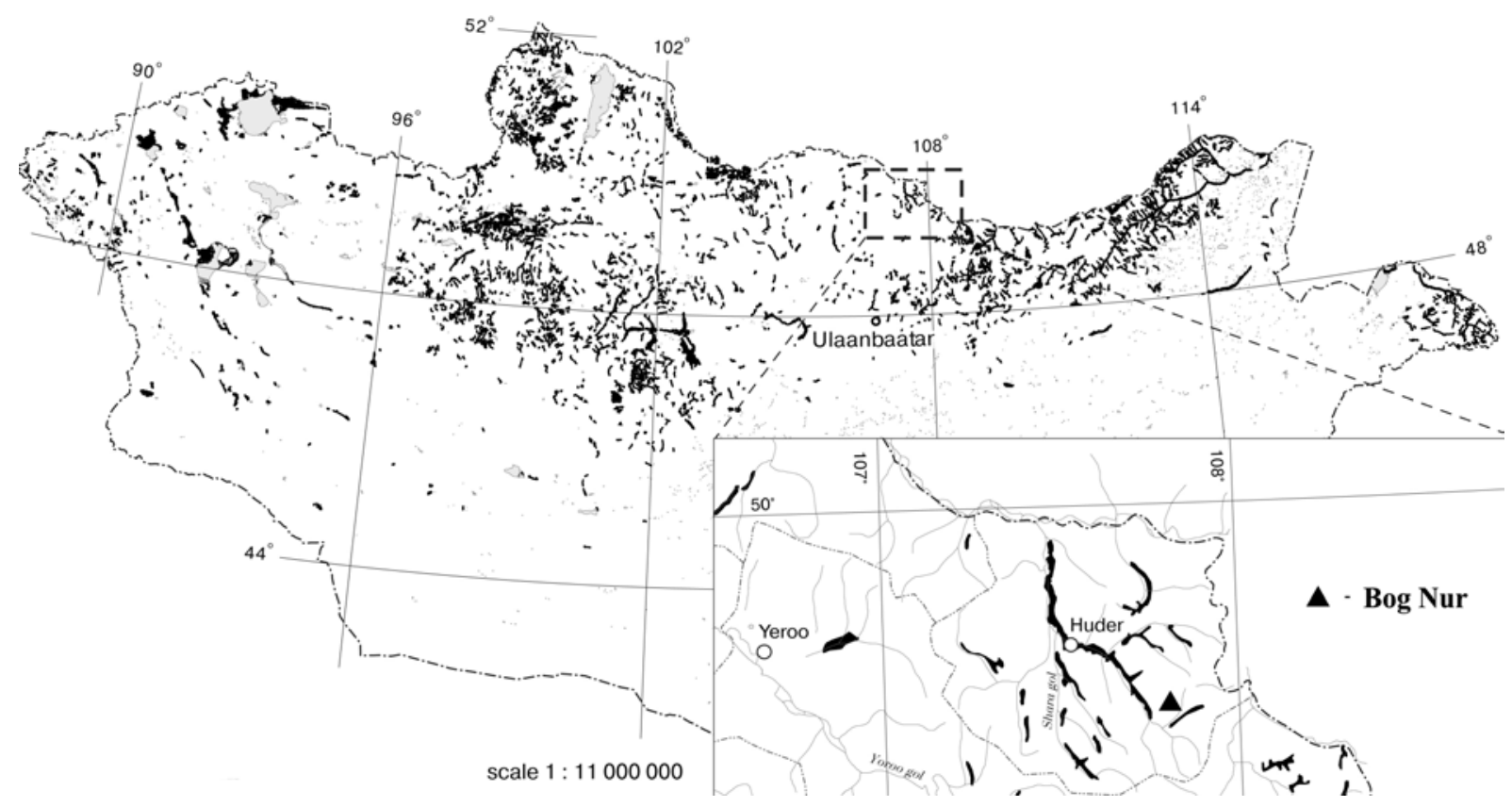

Fig. 1. Geographical position of the Nur Bog in Mongolia. 
palustris, Carex chordorrhiza, C. limosa, C. cinerea. Tree layer is formed by Betula platyphylla, Pinus sylvestris, Picea obovata, Abies sibirica. Vegetation and other characteristics have been described in details by Minayeva et al. (2008).

The diatom material is deposited at collection of A. Witkowski (SZCZ) in Marine Sciences Institute University of Szczecin (Szczecin, Poland).

Preparation of the diatom samples for microscopic observation followed the method by BALONOv (1975). An aliquot of each sample was placed in a glass test-tube to which hydrogen peroxide and potassium dichromate were added. After 3-5 minutes of reaction the samples were washed four times with distilled water. Clean valves were mounted in Naphrax ${ }^{\circledR}$. Light microscopic (LM) observations were carried out with a Nikon Eclipse E 600 microscope equipped with a 100x Plan-Apochromat 1.4 (i.a.) oil immersion objective and photographed using a Nikon DS-5M digital camera. The ultrustructure of diatom valves was analyzed by means of a LEO-1420 scanning electron microscope.

Identification and comparisons between species were mainly based on KRAMMER (1982, 1997a, 1997b, 2003). The terminology is based on KRAMMER (1982). Relative to the discussion regarding the measurement of striae in pennate diatoms, and especially in Cymbella s.l. (e.g. Anonymous 1975, Krammer 1982, 2003), we report that the striae were measured alongside the axial area, next to the central nodule in the middle of the valve.

\section{Results}

Our study of Nur Sphagnum bog from mountainous part of Mongolia revealed a species rich diatom assemblage with numerous cymbelloid species including several taxa with unclear taxonomic position. Description of new taxa and combinations are given below.

\section{Cymbopleura laticapitata (KRAMMER) Kulikovskiy et LANGE-Bertalot, stat. nov.}

\section{(Fig. 2: a-d, x)}

Basionym: Cymbopleura naviculiformis var. laticapitata KRAMMER 2003. Diatoms of Europe vol. 4. p. 157. Figs 79: 1-12.

Description: Valves slightly dorsiventral and more linear in comparison to $C$. naviculiformis (Fig. 2: a-d, x). Ventral margins are straight and dorsal margins are weakly convex (Fig. 2: a-d, $\mathrm{x}$ ) with abruptly capitate protracted ends (Fig. 2: a-d, x). Valve length 41-43.3 $\mu \mathrm{m}$, breadth 9.3-10.3 $\mu \mathrm{m}$, length/breadth ratio 4.1-4.7. Axial area narrow, linear becoming slightly broader towards the central area, almost in the median line of valve. Central area round, slightly rhomboid and expanding abruptly from the central nodule up to $1 / 2-2 / 3$ of the valve breadth (Fig. 2 : a-d, $\mathrm{x})$. Raphe typical for the $C$. naviculiformis-group, lateral, becoming filiform towards the proximal and distal ends. Outer raphe fissures ventrally displaced in the proximal part for about $1 / 4$ of the raphe branch length. Proximal raphe ends very slightly expanded as central pores and ventrally tipped. Terminal fissures somewhat undulate comma-shaped and dorsally deflected (Fig. 2: $\mathrm{a}-\mathrm{d}, \mathrm{x})$. Striae radiate throughout, $15-17 / 10 \mu \mathrm{m}$, areolae in LM barely resolvable, $32 / 10 \mu \mathrm{m}$ (Fig. 2: $\mathrm{a}-\mathrm{d}, \mathrm{x})$.

Distribution: This species is known so far from its type locality in Vittangi, Swedish Lapland and gyttja from a moor bog (KRAMMER 2003).

\section{Cymbopleura pernaviculiformis KULIKOVSKIY, Lange-Bertalot et Dorofeyuk, sp. nov.}

\section{(Fig. 2: e-h, y)}

Synonyms: Cymbopleura (? aff.) naviculiformis (Auerswald) in Lange-Bertalot et Genkal (1999: Taf. 56, 11); Cymbopleura naviculiformis (AUERSWALD) Krammer in Krammer (2003: Pl. 79, 13).

Descriptio: Diagnosis differens versus Cymbopleura naviculiformis (AUERSWALD) KRAMMER 2003 sensu stricto

Valvae generaliter similes quoad dimensiones et lineamenta tamen constanter differentes quoad rationem longitudo/latitudo 2.9-3.4 (non 3.3-4.4). Longitudo 28.7-34.4, latitudo 10-10.7 $\mu \mathrm{m}$. Raphe et areae axiales centralesque circiter aequales. Striae transapicales $14-17$ in $10 \mu \mathrm{m}$, radiantes omnino.

Description: Differential diagnosis versus Cymbopleura naviculiformis (AUERSWALD) KRAMMER 2003 s. str.

Valve outlines and size dimensions of both taxa similar with exception of the ratio of length/ breadth that is consistently lower in all cell cycle stages of C. pernaviculiformis populations from Mongolia and from Yugorsky-Shar Strait tundra, 2.9-3.4 (instead of 3.3-4.4). Length 28.7-34.4 $\mu \mathrm{m}$, breadth $10-10.7 \mu \mathrm{m}$ (i. e. on average more than 8.7-9.3 of the type population of $C$. naviculiformis). Raphe, axial- and central area are not significantly differentiated. Transapical striae $14-17$ in $10 \mu \mathrm{m}$ becoming denser towards 

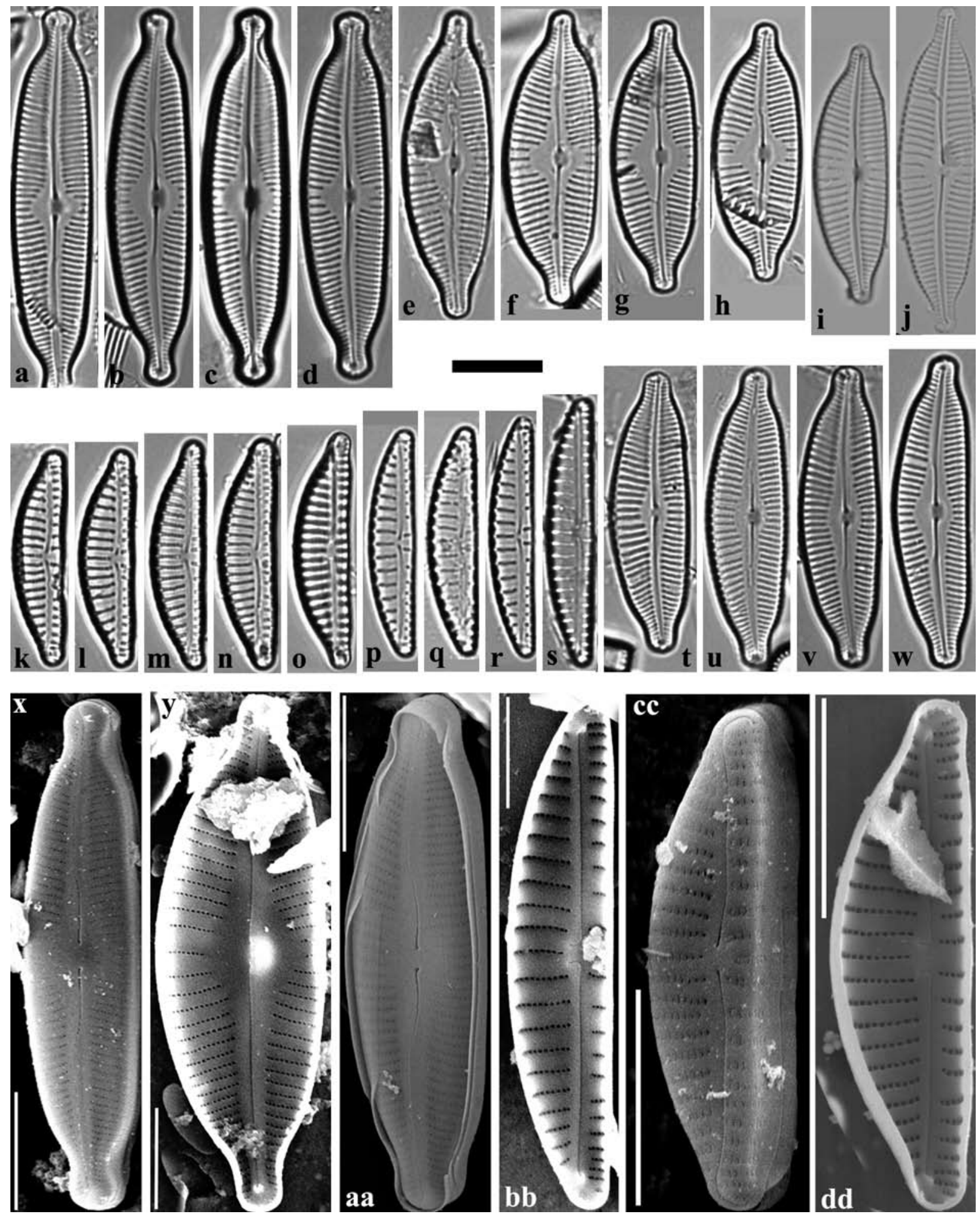

Fig. 2. (a-d, x) Cymbopleura laticapitata stat. nov.; (e-h, y) Cymbopleura pernaviculiformis sp. nov.; (i, j) Cymbopleura naviculiformis (AuERswald) Krammer, note the difference in the raphe fissures shape; ( $\mathrm{t}-\mathrm{w}, \mathrm{aa})$ Cymbopleura deviatkinii $\mathrm{sp}$. nov.; (p-s, bb) Encyonema groenlandica stat. nov. et comb. nov.; (k-o, cc, dd) Encyonema marvanii sp. nov. LM: a-w; SEM: $\mathrm{x}$, aa, cc - external valve view; $\mathrm{y}, \mathrm{bb}, \mathrm{dd}$ - internal valve view. Scale bar $10 \mu \mathrm{m}$. 
the ends, c. 20 in $10 \mu \mathrm{m}$. Areolae 27-33 in $10 \mu \mathrm{m}$. SEM internal view (Fig. 2: y). The pattern of striae ultrastructure is not significantly differentiated when compared with $C$. naviculiformis.

Holotypus: slide no. 12519 (see Fig. 2, f) in collection of A. WitKowsKi, Institute of Marine Sciences, University of Szczecin (SZCZ), leg. N. DOROFEYUK.

Isotypus: Slide no. 3 in collection of $\mathrm{M}$. KulikovskiY, Institute for Biology of Inland Waters (IBIW), Borok, Russia.

Locus typicus: Nur Sphagnum bog, northen Hentei highlands (N49'38'; E10748', 1348-1351 m a.s.l), Mongolia, 05. 09. 2005.

Etymology: "Per" in Latin means in this context similar but not identical.

Distribution: As yet only observed in Central Asia and a tundra lake of the Yugorsky Shar Strait area at the coast of the Arctic Ocean.

\section{Cymbopleura deviatkinii KULIKovSKIY, LANGE- Bertalot et Dorofeyuk, sp. nov.}

(Fig. 2: t-w, aa)

Descriptio: Diagnosis differens versus Cymbopleura declivis Metzeltin et Krammer in Krammer 2003.

Valvae modice vel distinctius dorsiventrales elliptico-lanceolatae marginibus dorsalibus interdum leniter triundulatis et marginibus ventralibus aliquid variabiliter formatis. Apices abrupte curte protracti rostrati. Longitudo 31.3$35.3 \mu \mathrm{m}$, latitudo 8.7-10 (non 10.7-12.7) $\mu \mathrm{m}$. Ratio longitudo/latitudo 3.4-3.5. Raphe magis lateralis fissuris externis distincte undulatis (ita satis differt). Area axialis et area centralis conspicue variabiles. Striae transapicales radiantes omnino, 15-16 (nec 10-12) in $10 \mu \mathrm{m}$ in mediis partibus valvarum, prope apices circiter 18 in 10 $\mu \mathrm{m}$. Areolae 32-34 in $10 \mu \mathrm{m}$.

Cymbopleura fluminea (PATRICK et FreEse) LANGeBertalot et Krammer proprie differt valvis angustioribus lineari-ellipticis cum marginibus paene aequaliter curvatis utrimque.

Description: Differential diagnosis versus Cymbopleura declivis Metzeltin et Krammer in KRAMMER 2003.

Valves moderately to more distinctly dorsiventral, elliptic-lanceolate with occasionally weakly triundulate dorsal margins and more variable ventral margins. Ends abruptly short-protracted, rostrate. Length $31.3-35.3 \mu \mathrm{m}$, breadth $8.7-10$

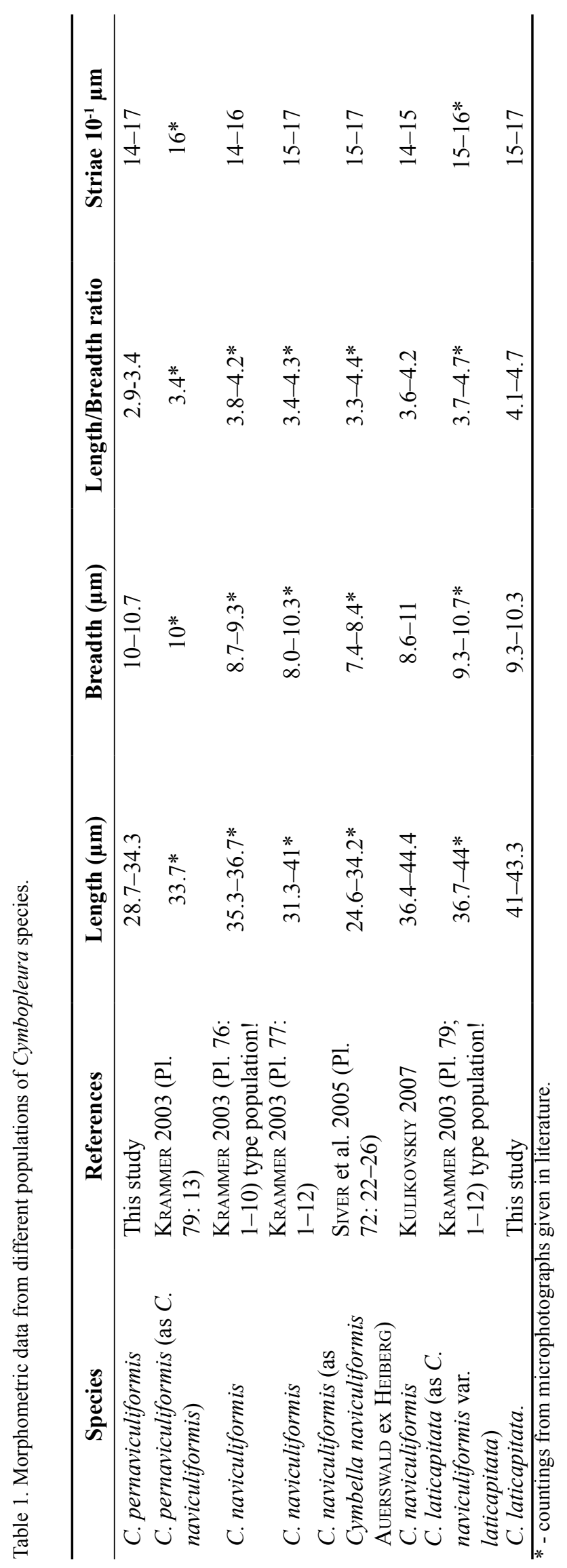


(not 10.7-12.7) $\mu \mathrm{m}$. Ratio length/breadth 3.4-3.5. Raphe lateral with distinctly undulating external fissures (not almost filiform). Axial and central areas vary considerably in shape. Transapical striae radiate throughout, 15-16 (not 10-12) in $10 \mu \mathrm{m}$, proximally becoming c. 18 near the ends. Areolae $32-34$ in $10 \mu \mathrm{m}$.

Cymbopleura fluminea (PAtrick et Freese) LangeBerTALOT et KRAMMER differs mainly in that it has narrower, linear-elliptical valves with almost equally curved dorsal and ventral margins.

Holotypus: slide no. 12529 (see fig. 2, u) in collection A. WitкоwsKi, Institute of Marine Sciences, University of Szczecin (SZCZ), leg. N. DOROFEYUK.

Isotypus: Slide no. 4 in collection M. KULIKOvsKIY, Institute for Biology of Inland Waters (IBIW), Borok, Russia.

Locus typicus: Sphagnum bog Nur, northen part of Hentei highlands $\left(49^{\circ} 38^{\prime} ; 107^{\circ} 48^{\prime}, 1348-1351\right.$ m a.s.1.), Mongolia, 05.09.2005.

Etymology: The species is dedicated to our colleague Dr. VLadimir DeviatKin who is currently studying the diatom flora from different ecosystems of Mongolia.

\section{Encyonema groenlandica (FogED) KULIKOVSKIY} et LANGE-BERTALOT, stat. nov. et comb. nov.

(Fig. 2: p-s, bb)

Basionym: Cymbella ventricosa var. groenlandica FoGED 1953. Diatoms from Pearyland, North Greenland. Meddr. Groenland, 1953, p. 57, Figs 10: 11-13.

Description: Valves weakly dorsiventral, dorsal margins convex, ventral margins straight, ends rounded (Fig. 2: r-o, bb). Length 25.3-32 $\mu \mathrm{m}$, breadth $5.2-6 \mu \mathrm{m}$, length/breadth ratio $4.8-5.3$. Axial area moderately narrow, central area absent (Fig. 2: r-o). Raphe filiform, curved, proximally turned to the dorsal side, terminal fissures ventrally bent. On the inside of valve, the proximal raphe endings are widely spaced with a wide intermissio between the two raphe branches and the raphe fissures possess an intermissio (Fig. 2: $\mathrm{r}-\mathrm{O}, \mathrm{bb}$ ). Transapical striae parallel, on the ventral side the two central striae are longer than the other ones. The striae become more closely spaced towards the apices of the valve (Fig. 2: r-o, bb). Striae in the valve centre, 5-6 in10 $\mu \mathrm{m}$. Each stria is composed of relatively small round areolae (Fig. $2: b b)$.

Distribution: This species is known from Nur
Sphagnum bog in Mongolia (this study), West Greenland and Iceland (FogED 1953, 1974).

\section{Encyonema marvanii KulIKovsKIY, LANGE- Bertalot, Witkowski et Dorofeyuk, sp. nov.} (Fig. 2: k-o, cc, dd)

Synonyms: Cymbella affinis var. semicircularis Lagerstedt sensu Cleve-Euler, 1955: 1178, p; Encyonema (? nov.) spec. in LANGe-Bertalot \& GenKal (1999: Fig. 61, 9).

Descriptio: Diagnosis differens versus Encyonema paucistriatum (CLEVE-EULER) D.G. MANN.

Valvae semi-ellipticae marginibus ventralibus paene rectis interdum levissime undulatis in medio paulo convexis aut concavis marginibus dorsalibus distincte arcuatis. Apices leviter protracti (non simpliciter rotundati). Longitudo 24-30 $\mu \mathrm{m}$, latitudo 6-7 $\mu \mathrm{m}$. Ratio longitudo/ latitudo 3.8-4.3 (nec circiter 5.3).

Raphe et area axialis conformantes in speciebus duobus. Area centralis vacans. Striae transapicales subparallelae in media parte valvae tum modice radiantes ad latera dorsalia ventraliaque, 7.5-8.5 in $10 \mu \mathrm{m}$ sed paucis striis ventraliter sub apicibus distincte densius sitis, ibi 13-15 in $10 \mu \mathrm{m}$. Areolae difficulter discernendae microscopio photonico, circiter 18-19 ultramicroscopio (vide Fig. 2: cc, dd).

Description: Differential diagnosis versus Encyonema paucistriatum (CleVE-Euler) D.G. ManN. Valves semi-elliptical, ventral margins almost straight, sometimes appearing slightly undulate, in the middle very slightly convex or concave; dorsal margins distinctly convex, arcuate. Ends gently protracted (not simply rounded). Length 24-30 $\mu \mathrm{m}$, breadth 6-7 $\mu \mathrm{m}$. Length to breadth ratio 3.8-4.3 (not about 5.3). Raphe and axial area conforming in both taxa. Central area lacking. Transapical striae sub-parallel on the dorsal side becoming moderately radiate, on the ventral side slightly radiate throughout, 7.5-8.5 in $10 \mu \mathrm{m}$ on either side but a few ventral striae are abruptly more closely spaced near the ends, $13-15$ in $10 \mu \mathrm{m}$. Areolae more densely spaced, 18-19 (not 24-28) in $10 \mu \mathrm{m}$. SEM external and internal view see Fig. 2, cc, dd. Fine structures as commonly occurring in Encyonema.

Holotypus: slide no. 12524 (see Fig. 2, 1) in collection A. Witкowski, Institute of Marine Sciences, University of Szczecin (SZCZ), leg. N. 
DOROFEYUK.

Isotypus: Slide no. 5 in collection M. KULIKOVsKIY, Institute for Biology of Inland Waters (IBIW), Borok, Russia.

Locus typicus: Sphagnum bog Nur, northern part of Hentei highlands $\left(49^{\circ} 38^{\prime} ; 107^{\circ} 48^{\prime}, 1348-1351\right.$ $\mathrm{m}$ a.s.1.), Mongolia, 05.09.2005.

Etymology: this taxon is dedicated Dr. Petr MARVAN in recognition of his contribution to the development of algological studies.

Distribution: So far found in Mongolia, Yugorsky-Shar Strait and Swedish Lapland (see Cleve-Euler 1955, Fig. 1177).

\section{Ecology and associated flora}

The discovery of the above mentioned species in a large oligotrophic bog as well as in other holarctic ecosystems allows us to consider them as characteristic elements of diatom assemblages of the arctic-alpine diatom flora. These species prefer oligotrophic, humic habitats with low $\mathrm{pH}$. Samples containing these species were dominated by Eolimna vekhovii (LANGE-BERTALOT et Genkal) Lange-Bertalot et Kulikovskiy, Nupela impexiformis (LANGE-BerTaLOT) Lange-Bertalot, Stenopterobia anceps (Lewis) BRÉBISSON, Tabellaria flocculosa (Rотн) KÜTZING, Kobayasiella parasubtilissima (KoBAyAsI et Nagumo) Lange-Bertalot, Gomphonema montanum Schumann, Frustulia crassinervia (Brébisson) Lange-Bertalot et Krammer, Chamaepinnularia mediocris (KRASSKE) LANGEBertalot et Krammer and Adlafia suchlandtii (Hustedt) Lange-Bertalot. These species are found in abundance in oligotrophic lakes of Finland, Novaya Zemlya Island (LANGe-BerTalot \& Metzeltin 1996, Lange-Bertalot \& Genkal 1999, Genkal \& Vekhov 2007). Aulacoseira spp. abundant in Nur bog is distinctive for the diatom flora of Sphagnum bogs in the European part of Russia (GenKal \& KULIKovsKiY 2006; KULIKOVSKIY 2007). Aulacoseira alpigena (Grunow) Krammer, A. lirata (EHRENBERG) Ross and A. septentrionalis (CAmburn et Charles) Genkal et Kulikovskiy found in Nur bog are known, from low-alkalinity lakes of North America and holarctic ecosystems in the European and Asian part of Russia (e.g. Camburn \& Kingston 1986, Camburn \& Charles 2000, GenKal \& KuLIKovsKiY 2006, Yarushina \& GeNKAL 2006).

\section{Discussion}

Krammer (1997a,b, 2002, 2003) discussed the problems with identification and groupings of cymbelloid diatoms. The principal size characteristics e.g. valve length, breadth and length/breadth ratio as well as the shape of the ends are very important for identification. However, valve shape can be also important KRAMMER (2003), for example into the Cymbopleura naviculiformis-group for distinguishing taxa such as Cymbopleura sublanceolata Krammer, Cymbopleura naviculiformis var. laticapitata Krammer and Cymbopleura amphicephala (Naegeli) Krammer.

Cymbopleura naviculiformis (AUERSWALD) KRAMMER was frequently misidentified in the past. The morphological variability of this taxon from the type material together with specimens from other habitats have been illustrated by KRAMMER (2003). Illustrations of the type material delivered by KRAMMER (2003) served as comparison for other authors in their studies. This was specially important for ultrastructural studies which involved SEM examination of the valves. Such attempts were undertaken by e.g. Siver et al. (2005) in Lakes of Cape Code in the United States and KulikovskiY (2007) in a population from a Sphagnum bog in the European Russia. SEM investigations of $C$. naviculiformis from a Russian bog revealed that the valves are characterised by absence of intermissio and the smaller extended raised central nodule in internal view, smaller helictoglossae that agree with Krammer's figures (2003: Pl. 78, 1) but not with Krammer (1982) where a heterogeneous collection of valves is presented. The central area of $C$. naviculiformis is fairly variable and may extend for about $1 / 2$ $2 / 3$ of the valve breadth (KRAMMER 2003) or can be very small, almost lacking (cf. Siver et al. 2005, KulikovskiY 2007). In Figure 2: i, j C. naviculiformis from Russian bog are illustrated for comparison with other species.

When the two species are compared, Cymbopleura pernaviculiformis is distinguished from $C$. naviculiformis by the pronounced intermissio, more raised helictoglossae and a large circular central nodule. Ends of $C$. pernaviculiformis are always broadly rostrate, whereas in $C$. naviculiformis they are longer, narrow-rostrate to capitate. Of importance in this group of species is the valve width. When this feature is considered, C. pernaviculiformis is 
always broader than the latter taxon. The ventral margin is always straight and more parallel to the axial area whereas in C. naviculiformis the ventral margin is slightly arched, straight or slightly convex in the central part (cf. KRAMMER 2003, Siver et al. 2005).

For comparative analysis of size ranges, morphometric data were taken from micrographs of the type population of $C$. naviculiformis and a population from a pond in southern Germany, illustrated in KRAMMER (2003), and in addition the range of variation recorded by SIVER et al. (2005) (Table 1). C. pernaviculiformis has a length/ breadth ratio that separates this species from $C$. naviculiformis (Table 1). Using these data, the valve that was documented by LANGE-BERTALOT \& GenKAL (1999: P1. 56: 11) and later transferred to C. naviculiformis by KRAMMER (2003: Pl. 79: 13), we should identify as C. pernaviculiformis.

Krammer (2003) also described Cymbella naviculiformis var. laticapitata. Our observations of valve outline and other parameters show that this entity deserves a separate status at the species rank. It differs from C. naviculiformis with respect to valve outline (distinctly lower variability) and a higher length/breadth ratio than C. naviculiformis (Table 1). In this paper a formal transfer of Cymbopleura naviculiformis var. laticapiata into Cymbopleura laticapitata is proposed.

Likewise Cymbopleura deviatkinii is related to the $C$. naviculiformis-group. The major character shared between the two taxa is raphe morphology. Even if the raphe is crucial for distinguishing its phylogeny, $C$. deviatkinii is very easily distinguished from other similar taxa, i.e. Cymbella naviculiformis and C.pernaviculiformis, by shape, denser striation on the dorsal valve side, and length/breadth ratio (Table 1). $C$. naviculiformis and $C$. pernaviculiformis have irregularly arranged striae in the central area of the dorsal side, whereas $C$. deviatkinii shows some similarity to Cymbopleura fluminea (PATRICK et Freese) Lange-Bertalot et Krammer, but can be distinguished by wider valves and indistinctly punctate-lineate striae (KRAMMER 2003).

In the material studied we have found several species of Enyconema. Two taxa under study (Encyonema groenlandica, E. marvanii) were previously described as infraspecific taxa. Both are small-celled species.

Our new species Encyonema marvanii has been confused with Cymbella affinis var. semicircularis LAGERSTEDT (syn. Encyonema latens (Krasske) D.G. Mann sensu Krammer 1997). This misidentification resulted from a mistake in "matches" the drawing of this taxon by Cleve-Euler. Cleve-Euler illustrated a single valve from Lapland (Cleve-Euler 1955, Fig. 1178p) as Cymbella affinis var. semicircularis. Independently, LANGE-Bertalot \& GenKaL (1999) depicted a single valve of this taxon as "Encyonema (? nov.)" from Yugorsky-Shar Strait in the Arctic Ocean. This image corresponds with Encyonema marvanii as illustrated here and matchches very well with the characteristics of this species. Hence the distribution of E. marvanii, so far as is known is limited to northern Scandinavia, Mongolian Sphagnum bog and Yugorski Shar area in the Arctic.

Similarly, E. groenlandica was described as Cymbella ventricosa var. groenlandica Foged from West Greenland (FogED 1953). Later, this variety was also identified from Iceland (FogED 1974). The morphological features of this species are distinct from Cymbella (Encyonema) ventricosa, therefore we suggest a new taxonomic status and make its transfer to Encyonema. E. groenlandica is characterized by the long ventral terminal fissures, proximal raphe ends which are bent dorsally and the outer raphe fissure which is bent to the ventral margin. The latter character is an important characteristic in the delimitation of the genus Encyonema sensu Krammer (KRAMMER 1997a, b, 2002).

\section{Acknowledgements}

A research visit of Dr. M. Kulikovskiy to the Institute of Marine Sciences, University of Szczecin was financed by the Mianowski Fund (Warsaw) and University of Szczecin. English language corrections of the manuscript made by Dr. Jonathan Taylor are acknowledged. The authors are grateful to Dr. J. Patrick Kociolek for critical reading of the manuscript.

\section{References}

Ando, K. (1977): Moss diatoms in Japan. - Bull. Jap. Soc. Phycol. 25: 195-201.

Ando, K. (1978): Moss diatoms in Japan (2). - Jap. J. Phycol. 26: 125-130.

ANONYMOUS (1975): Proposals for a standardization of diatom terminology and diagnoses. - Nova Hedwigia, Beiheft 53: 323-354.

Antoniades, D., Hamilton, P. B., Douglas, M. S. V. \& SmoL, J. P. (2008): Diatoms of North America: The freshwater floras of Prince Patrick, Ellef Ringnes and northen Ellesmere Islands from the 
Canadian Arctic Archipelago. - Iconographia Diatomologica 17: 1-649.

Balonov, I.M. (1975): Preparing algae for electron microscopy. - In: MordukHai-Boltovskoi, F.D. (ed.), Methods of studying biogeocenoses of inland waters. - pp. 87-90, Nauka, Moscow.

Buczko, K. (2006): Bryophytic diatoms from Hungary. - In: Witkowski, A. (ed.), Proceeding of 18 International Diatom Symposium. - pp. 1-15, Biopress Limited, Bristol.

Camburn, K.E. \& Charles, D.E. (2000): Diatoms of low-alkalinity lakes in the Northeastern United States. - 152 pp., Academy of Natural Sciences of Philadelphia, Philadelphia.

Camburn, K.E. \& Kingston, J.C. (1986): The genus Melosira from soft-water lakes with special reference to northern Michigan, Wisconsin and Minnesota: Diatoms and lake acidity. - pp. 1734, Dr. W.Junk, Dordrecht.

Cleve-Euler, A. (1955): Die Diatomeen von Schweden und Finnland. Kongl. Svenska. - Vet. Akad. Handl. Serie, 5/4: 1-232.

Douglas, M.S.V. \& Smol, J.P. (1995): Periphytic diatom assemblages from high arctic ponds. $-\mathrm{J}$. Phycol. 31: 60-69.

Douglas, M.S.V. \& Smol, J.P. (1999): Freshwater diatoms as indicators of environmental change in the High Arctic. - In: Stoermer, E.F. \& Smol, J.P. (eds): The Diatoms: Applications for the Environmental and Earth Sciences. - pp. 227243, Cambridge University Press, Cambridge.

Edlund, M.B., Williams, R.M. \& Soninkhishig, N. (2003): The planktonic diatom diversity of ancient Lake Hovsgol, Mongolia. - Phycologia 42: 232-260.

Edlund, M.B., Levkov, Z., Soninkhishig, N., Krstic, S. \& NAKov, T. (2006a): Diatom species flocks in large ancient lakes: the Navicula reinchardtii complex from Lakes Hövsgöl (Mongolia) and Prespa (Macedonia). - In: Witkowski, A. (ed.): Proceeding of 18 International Diatom Symposium. - pp. 61-74, Biopress Limited, Bristol.

Edlund M.B., Soninkhishig N. \& Stoermer F. (2006b): The Diatom (Bacillariophyceae) flora of Lake Hövsgöl National Park, Mongolia. - The Geology, Biodiversity and Ecology of Lake Hövsgöl (Mongolia). Leiden, 2006. P. 145177.

Foged, N. (1953): Diatoms from West Greenland. Medd. om Groenland 147: 1-86.

Foged, N. (1974): Freshwater diatoms in Iceland. Bibliotheca Phycologica 15: 1-192.

Genkal, S.I. \& Vekhov, N.V. (2007): Diatoms from waterbodies of Russian Arctic. - p. 63, Moscow, Nauka.

Genkal, S.I. \& Kulikovskiy, M.S. (2006): Centric diatoms in the sphagnum bogs of Privolzhskaya hills (Penza region). - Botanical Journal 10: 1485-1499.

Gremmen, N.J.M., Van de Vijver, B., Frenot, Y. \& LeBOUVIER M. (2007): Distribution of mossinhabiting diatoms along an altitudinal gradient at sub-Antarctic Iles Kerguelen. - Antarctic Science 19: 17-24.

Gunin, P.D. \& Vostokova, E.A. (2005): Ecosystems of Mongolia. -48 pp., Atlas, Moscow.

KrAmmer, K. (1982): Valve morphology in the genus Cymbella C.A. Agardh. - Micromorphology of Diatom Valves 11: 1-299.

Krammer, K. (1997a): Die cymbelloiden Diatomeen. Teil 1. Allgemeines und Encyonema part. -Bibliotheca Diatomologica 36: 1-382.

Krammer, K. (1997b): Die cymbelloiden Diatomeen. Teil 2. Encyonema part., Encyonopsis und Cymbellopsis. - Bibliotheca Diatomologica 37: $1-469$.

Krammer, K. (2002): Cymbella. - Diatoms of Europe 3: $584 \mathrm{pp}$.

Krammer, K. (2003): Cymbopleura, Delicata, Navicymbula, Gomphocymbellopsis, Afrocymbella - Diatoms of Europe 4: 530 pp.

KuLIKovskiY, M.S. (2007): Diatoms of some Sphagnum bogs from the European part of Russia. - 24 pp., Ph.D. thesis, St. Petersburg. (in Russian)

Kulikovskiy, M.S. (2008): The species composition and distribution of diatoms in sphagnum bogs of European Russia: Ecosystems of the Volga Upland. - Inland Water Biology 1: 347-355.

KulikovskiY, M.S. (2009): The species composition and distribution of diatoms in sphagnum bogs of European Russia: The Polistovo-Lovatskii Land Tract. - Inland Water Biology 2: 135-143.

Lange-Bertalot, H. \& GenKal, S.I. (1999): Diatoms from Siberia I. - Iconographia Diatomologica 6: 1-292.

Lavrenko, E.M. (2000): About the Central Asian mountain sedge fen and Siberia-Mongolian elements in the Caucasus flora. - pp. 591-603, Selected works, Sankt-Petersburg.

LANGe-Bertalot, H. \& Metzeltin, D. (1996): Indicators of oligotrophy. Iconographia Diatomologica, 2. - 390 pp., Koeltz Scientific Books, Königstein.

Lavrenko, E.M. (2000): About the Central Asian mountain sedge fen and Siberia-Mongolian elements in the Caucasus flora-E.M. Lavrenko. Selected works. Sankt-Petersburg, 591-603.

Metzeltin, D., Lange-Bertalot, H., Soninkhishig, N. (2009): Diatoms in Mongolia - Iconographia Diatomologica 20: 1-684.

Minayeva, T., Sirin, A., Dorofeyuk, N. (2005): Mongolian mires: from taiga to desert. - Stafia 85, zugleich Kataloge der OÖ. Landesmuseen Neue Serie 35: 335-352.

Minayeva, T.Yu., Andreev, A.V., Bayasgalan D., Bazha, S.N., Cherdonova, V.A., Dorofeyuk, 
N.I., Drobyshev, Yu.I., Dugarjav, Ch., Gunin, P.D., PrischePa, A.V., Sirin, A.A., Slemnev, N.N., Smagin, V.A., Surikova, P.M., Tsedendash, G., TsetsegmaA, D., Ubugunov, L.L., Ubugunova, V.I., Vorobyov, K.A. \& Zoyo, D. (2008): Mire ecosystems of Mongolia. - pp. 95-175, Moscow, Nauka.

Pavlov, N.V. (1929): Introduction to the vegetation of Hangai highlands. - pp. 3-72, Preliminary report of the botanical expedition in North Mongolia in 1926, Leningrad.

Popovskaya, G.I., Genkal, S.I. \& Likhoshway Ye.V. (2002): Diatoms of the plankton of Lake Baikal. Atlas and key. - 168 pp., Novosibirsk, Nauka.

PoulíčKová, A., Duchoslav, M., Hekera, P., Hájková, P. \& NovotnÝ, R. (2002): Ecology of diatoms of sloping springs in the flysh area of the West Carpathians. - In: Economou-Amilli, A. (ed.): Proceedings of the $16^{\text {th }}$ International Diatom Symposium. - pp. 225-236, Amvrosiou Press, Athens, Greece.

Poulíčková, A., Hájková, P., KŘenková, P. \& Hájek, M. (2004): Distribution of diatoms and bryophytes on linear transects through spring fens. - Nova Hedwigia 78: 411-424.

Siver, P.T., Hamilton, P.B., Stachura-Suchoples, K. \& Kociolek, P. (2005): Diatoms of North America. The Freshwater Flora of Cape Cod. Iconographia Diatomologica 14: $463 \mathrm{pp}$.

Temniskova-Topalova, D. \& Chipev, N. (2001): Diatoms from Livingston Island, The SouthShetlands, Antarctica. - In: EconOMOU-Amilli, A. (ed.): Proceedings of the $16^{\text {th }}$ International Diatom Symposium. - pp. 291-314, Amvrosiou Press, Athens, Greece.
VAn de ViJver, B. \& Beyens, L. (1996): The epithytic diatom flora of mosses from Stromness Bay area, South Georgia. - Antarctic Science 8: 359-368.

Van de Vijver, B., Ledeganck, P. \& Beyens, L. (2001): Habitat preferences in freshwater diatom communities from sub-Antarctic Iles Kerguelen. - Antarctic Science 13: 28-36.

Van de Vijver, B., Frenot, Y. \& Beyens, L. (2002): Freshwater diatoms from Ile de la Possession (Croset Archipelago, Subantarctica). Bibliotheca Diatomologica 46: 1-412.

Wojtal, A., Witkowski, A. \& Metzeltin, D. (1999): The diatom flora of the "Bor na Czerwonem" raised peat-bog in the Nowy Targ Basin (Southern Poland). - Fragmenta Floristica et Geobotanica 44: 167-192.

Yanatov, A.A. (1950): Characteristic features of the vegetation of Mongolia. - 224 pp., Moscow, Leningrad.

YARUSHINA, M.I. \& GENKAL, S.I. (2006): A contribution to studies of the flora of centric diatoms (Centrophyceae) in reservoirs of the eastern mountainside of the Polar Urals (Russia). - Int. J. Algae 4: 308-322.

(C) Czech Phycological Society

Received April 30, 2009

Accepted May 20, 2009 